\title{
Indirect Determination of Ethanol in Drinks Using a Capacitance Flow-through Detector
}

\author{
Shan-jun Liu, and Matthieu Tubino* \\ Instituto de Química, Universidade Estadual de Campinas, C.P. 6154, \\ 13083-970 Campinas - SP, Brazil
}

\begin{abstract}
Foi desenvolvido um método de análise para a determinação de vapor de água, baseado num sensor capacitimétrico. Este detetor consiste de dois tubos concêntricos de aço inoxidável e fica localizado no tubo de amostragem da válvula introdutora de amostra do sistema de fluxo. O logaritmo da capacitância dos vapores de amostra (sinal analítico) apresenta uma boa correlação linear com a concentração de vapor de água numa faixa de 1705 até $2197 \mathrm{~Pa}$. Cerca de 55 amostras podem ser analisadas por hora. Este sistema de fluxo foi aplicado à determinação indireta da concentração de etanol em bebidas alcoólicas, em função da concentração do vapor de água presente no frasco contendo o líquido em análise. Não é necessário nenhum pré-tratamento da amostra. Corantes presentes na bebida não interferem nos resultados.

A flow procedure based on a metallic capacitance flow-through detector is described for the analysis of water vapour. The capacitance detector consists of two stainless steel tubes and is located in the loop of a sampling valve. The logarithm of the capacitance signal correlates linearly with the concentrations of water vapour in the 1705 to $2197 \mathrm{~Pa}$ range. A sampling frequency of about $55 \mathrm{~h}^{-1}$ can be achieved. The flow system was applied to the indirect determination of the ethanol concentration in drinks based on the analysis of water vapour content above the liquid sample, without any pre-treatment of the sample. The colour of the drinks has no effect on the measurements.
\end{abstract}

Keywords: capacitance, water vapour, ethanol, drinks, flow analysis

\section{Introduction}

The capacity is defined as the charge that the capacitor can store per unit of potential difference between the plates. The capacity of a condenser is increased by interposing a dielectric material between the plates. In tensammetry the capacitance of the electrical double layer of an electrode is measured. The capacitance value is strongly influenced by the presence of absorbing species ${ }^{1}$. Although tensammetry is possible at all kinds of electrode surfaces, mercury is the most widely used electrode material ${ }^{1}$. Detectors with mercury electrodes (dropping mercury ${ }^{2,3}$, hanging or static modes $^{4}$ and mercury-coated ${ }^{1}$ are mainly used for the determination of substances in solutions. Other electrode materials, based on the capacitance principle, have also been developed. A tantalum capacitance sensor is used for the detection of proteins by immunochemical binding reactions ${ }^{5}$. Berggren and Johansson immobilised monoclonal antibodies on gold substrates ${ }^{6}$. The antibody layers and their interactions with antigens in solution were investigated with capacitance measurements and with cyclic vol- tammetry. The capacitance change versus the logarithm of antigen concentration is linear over three decades ${ }^{6}$. A gassensitive semiconductor based on a palladium MOS fieldeffect capacitor for the determination of ammonia in air and aqueous solutions has also been described ${ }^{7}$. The main problem in preparing a stationary working electrode for tensammetric measurements is the formation of a homogeneous and well-defined surface ${ }^{1}$.

Double layers are not a special feature of the electrodeelectrolyte interfaces; they are a general consequence of the junction of two phases at a boundary ${ }^{8}$. Owing to its high dielectric constant $\left(78.5\right.$ at $\left.25^{\circ} \mathrm{C}\right)$ water is the primary species which can be measured by changes of the capacitance ${ }^{9}$. Many industrial processes, such as drying, baking, kilning, etc., involve the modification of a material water content. The measurement of humidity should rate equally in importance with the measurement of temperature in industry ${ }^{10}$. The aim of this work was to evaluate a proposed metallic capacitance detector for quantitative analysis of gases and to develop a fast procedure for measurement of water vapour in a flow system. The proposed method is 
further employed to measure indirectly the ethanol content in drinks. The use of the proposed metallic electrode circumvents the problem of the formation of a homogeneous and well-defined surface. Also, no renewal of surface is necessary.

\section{Experimental}

Vapours and gases

The vapours were obtained from their respective pure liquids. All organic solvents were of analytical or spectral grade. Dried air was obtained by passing air through a column packed with silica gel and sodium hydroxide. Carbon dioxide was obtained from a cylinder. Various concentrations of water vapour were prepared by saturating air with vapour from distilled water that was kept at various fixed temperatures and stirred continuously more than 30 min. The concentration of water vapour in air was obtained from the table of the vapour pressure of water at various temperatures ${ }^{11}$. Analytical grade ethanol $(96 \% \mathrm{v} / \mathrm{v})$ was used to prepare the different ethanol solutions with distilled, deionised water (ethanol:water, 0 to $96 \%$ by volume or weight).

\section{Apparatus}

The capacitance flow-through detector and related battery-powered electric circuit were laboratory-made. The construction of the capacitance detector has been previously described $^{12}$. The detector consists of two concentric stainless steel tubes, the external tube with an inside diameter of $1.8 \mathrm{~mm}$ and a length of $30 \mathrm{~mm}$ and the internal tube with an outside diameter of $1.2 \mathrm{~mm}$. The space volume of the detector is about $40 \mu \mathrm{L}$. The capacitance signal was measured with a battery-powered MX-901 (Minipa) digital multimeter and recorded on a chart recorder (Model RB 201, Equipamentos Científicos do Brasil, Brazil). An air pump was used to convey dried air for rinsing the detector. The sampling valve was made of polytetrafluoroethylene $(\mathrm{PTFE})^{13}$. The sample flask with liquid sample was immersed in a thermostatic water bath (MGW RCS 6, LaudaKönigshofen). A stop-watch was used to measure the sampling time.

\section{Procedure}

The flow system used to implement the proposed method is schematically shown in Fig. 1. The capacitance flow-through detector was located in the loop of sampling valve, and the sample introduction was carried out by keeping the sampling valve in the sampling position (VS) for 20 to $50 \mathrm{~s}$. Dried, filtered air was used to rinse the detector by switching the sampling valve to rinsing position (VR). The liquid samples were first maintained at a fixed temperature for more than $3 \mathrm{~h}$. Then about $20 \mathrm{~mL}$ sample was transported into a testing bottle $(40 \mathrm{~mL}) \mathrm{kept}$ at the



Figure 1. Schematic diagram of the flow system with the capacitance flow-through detector. (F) silica gel and sodium hydroxide packed column for air drying; (T) thermostatic water bath; (S) liquid sample in testing bottle; (VR) sampling valve in rinsing position; (VS) sampling valve in sampling position; (M) magnetic stirrer. Capacitance detector is within the sample coil. Arrows denote the flow directions of sample vapour and air.

same temperature. The peristaltic pump began to circulate air at a flow rate of $21 \mathrm{~mL} \mathrm{~min}^{-1}$ within the sample enclosure, bubbled through the liquid sample $(\mathrm{S})$, which was continuously stirred with a magnetic stirrer (M). The air was saturated with the vapour of the liquid sample for 30 min, then the measurements were started.

When the drink samples were analysed, the samples and the standard series were kept at room temperature more than one day and the vapour above the liquid sample was directly analysed one by one. Ethanol concentrations in drinks were obtained from the calibration curve.

\section{Results and Discussion}

The vapour pressure of water increases as the temperature increases ${ }^{11}$. In the present work, various water vapour pressures were obtained by means of changing the temperature of the water. The water vapour concentration (signal) increases with increasing equilibrium time of sample. After about 25 min, the signal becomes constant. This means that saturation of the air with water vapour was obtained in the analytical system. As the vapour equilibrium time influences the concentrations of water vapour and thus the capacitance signal, subsequent measurements were performed with a vapour equilibrium time of $30 \mathrm{~min}$ with the liquid sample.

\section{Response characteristics}

The capacitance detector provides a stable baseline, and for dried air the response is about $18 \mathrm{pF}$. The response of the detector to some gases or vapours, obtained from their respective pure liquids maintained at $20.0^{\circ} \mathrm{C}$, was tested in the flow system with a $50 \mathrm{~s}$ sampling time and a $15 \mathrm{~s}$ interval time. Capacitance values and vapour pressures of the tested pure substances are given in Table 1 . The response of water vapour is the highest, while room air, carbon dioxide, and vapours of methanol, ethanol and acetic acid hardly give 
Table 1. Capacitance signal and vapour pressure of tested substances in flow analysis*.

\begin{tabular}{lcc}
\hline Tested substance & Signal / $\mathrm{nF}$ & Gas or vapour pressure at $25^{\circ} \mathrm{C} / \mathrm{kPa}{ }^{14}$ \\
\hline Room air & 0.002 & $c a 101.3^{* *}$ \\
Carbon dioxide & 0.002 & $c a 101.3^{* *}$ \\
Water & 1.473 & 3.2 \\
Methanol & 0.001 & 16.7 \\
Ethanol & 0 & 8.0 \\
Benzene & 0.265 & $1.6^{24.5} * * *$ \\
Toluene & 0.819 & $0.8^{35.4 * * *}$ \\
Chloroform & 0.608 & 26.0 \\
Acetone & 0.017 & $24.2^{20}$ \\
Acetic Acid & 0.001 & 2.0 \\
\hline
\end{tabular}

* Liquid samples maintained at a temperature of $20.0^{\circ} \mathrm{C}$. Sampling and interval time $=50$ and $15 \mathrm{~s}$. Flow rates of sample and air carrier $=21$ and 330 $\mathrm{mL} \mathrm{min}^{-1}$. The detector operated at room temperature (about $22^{\circ} \mathrm{C}$ ).

** Carbon dioxide gas, obtained from a cylinder, and air directly introduced into the analytical system at a pressure of about $1 \mathrm{~atm}$.

*** Tomás Boublík; Vojtech Fried; Eduard Hála; Physical sciences data 17: The vapour pressure of pure substances, Selected values of the temperature dependence of the vapour pressures of some pure substances in the normal and low pressure region, 2nd., Elsevier, 1984.

responses. Therefore water vapour was chosen to study the response characteristics of the detector. A typical recorded curve for water vapour is shown in Fig. 2. The signal peak is asymmetric. The detector begin to respond to water vapour about $6 \mathrm{~s}$ after the sample vapour passes through the detector. When the sampling valve is switched to the rinsing position only the filtered dried air carrier is passing through the detector and the signal rapidly returns to baseline. The experiments were carried out with a stop-watch, and it can be expected that the application of solenoid valve control sampling may improve the repeatability of the measurements. It is necessary to use a sampling time longer than $6 \mathrm{~s}$ in order to obtain an observed signal. The time of $10 \mathrm{~s}$ is enough for returning the signal to the baseline, allowing the introduction of the next sample.

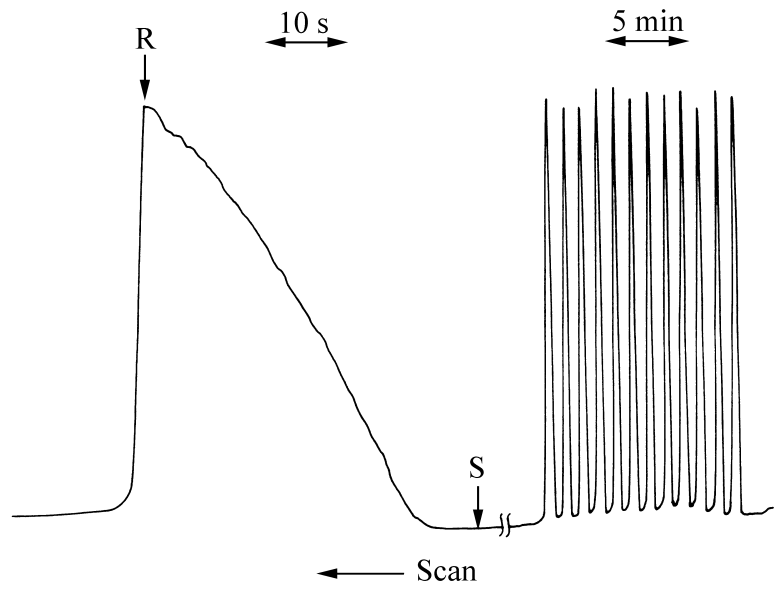

Figure 2. A recorded curve for the response of water vapour in the flow system. Water was maintained at $20.0^{\circ} \mathrm{C}$. Sampling $40 \mathrm{~s}$ and interval $20 \mathrm{~s}$. $\mathrm{S}$ was the time point of sampling and $\mathrm{R}$ was that of rinsing.
The effect of sampling time up to $90 \mathrm{~s}$ was evaluated and results are shown in Fig. 3. After a delay of several seconds, the signal rapidly increases as the time of sample vapour passing through the detector increases. Since the analytical frequency depends on the sampling time, a compromise between sample throughput and sensitivity was made, and a sampling time of 40-50 s and an interval time of $15 \mathrm{~s}$ were chosen. Thus, the analytical frequency is at least 55 samples $\mathrm{h}^{-1}$.

Another factor influencing the analytical signal is the flow rate of sample vapour. Below a flow rate of $20 \mathrm{~mL}$ $\mathrm{min}^{-1}$, the signal increases with increasing flow rate of

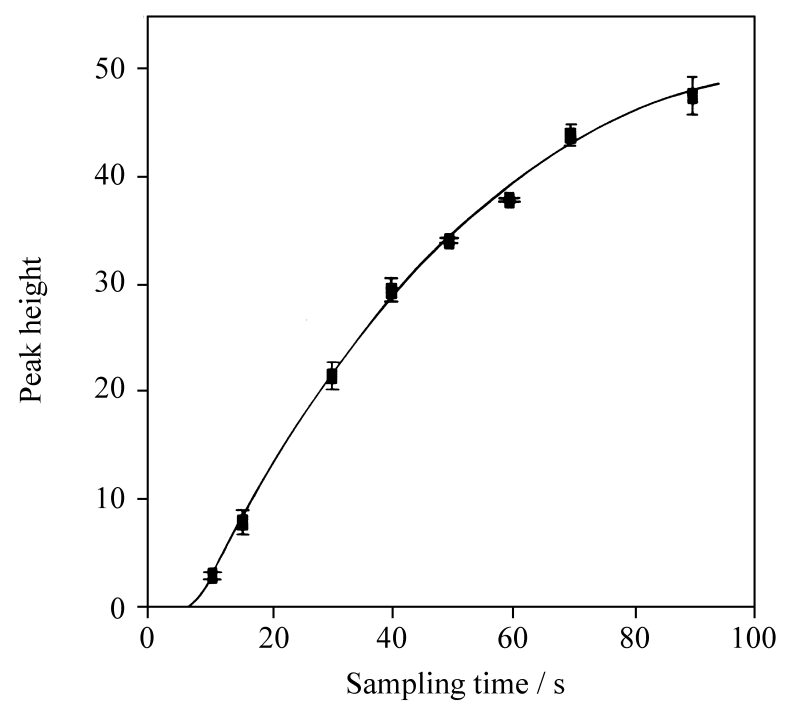

Figure 3. Effect of sampling time on the signal. Water was maintained at $20.0^{\circ} \mathrm{C}$. Interval time was $15 \mathrm{~s}$. Average values corresponding to four determinations at the same sampling time. 
water vapour; after $20 \mathrm{~mL} \mathrm{~min}^{-1}$ the signal remains constant. This fact may be understood in terms of the saturation of the electrode with the vapour. The sample flow rate was selected at $21 \mathrm{~mL} \mathrm{~min}^{-1}$.

\section{Relationship of the capacitance signal and the concentration of water vapour}

The relationship between the capacitance signal and the water vapour concentration was tested. The capacitance signal is not linear with respect to the concentration of water vapour. The logarithm of the net capacitance signal, measured as peak height, however, linearly correlates to the concentrations of water vapour in the range of 1705 to 2197 $\mathrm{Pa}$. This correlation is used as the calibration curve. The features of the determinations of water vapour with different sampling time are summarised in Table 2.

\section{Selectivity}

When the capacitance flow-through detector was used for the measurement of gases or vapours in the flow system, it shows some selectivity as it responds to only some organic vapours. The proposed method is suitable for welldefined samples, for example, indirect determination of ethanol in drinks as the water vapour pressure depends on the ethanol concentration of the solution.

\section{Analytical application: Indirect determination of ethanol in drinks}

Since ethanol has hardly response in the capacitance detector under the experimental conditions (see Table 1), the relationship between capacitance signal and ethanol content in water was studied and is shown in Fig. 4. The recorded signal is dependent on the concentration of ethanol in the sample. The logarithm of the analytical signal is inversely proportional to the ethanol content of the solution. The features of the determination of ethanol with different sampling times are also given in Table 2. The logarithm of the capacitance signal measured as peak

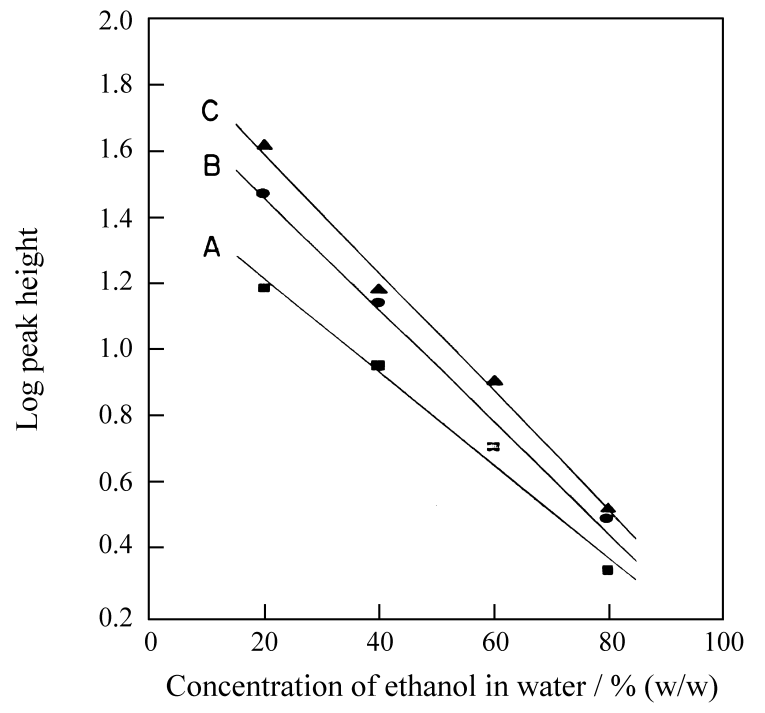

Figure 4. Calibration curves of logarithm of the capacitance signal and concentration of ethanol in water. Curves A, B and C indicate sampling times of 20, 40 and $60 \mathrm{~s}$, respectively.

height linearly correlates to the concentrations of ethanol in water over a limited working range.

The proposed method was applied to determine indirectly the ethanol content in drinks. The vapours of drink samples are analysed directly without any pre-treatment. The results obtained in this work are compared with those using the density method by another laboratory and given in Table 3. The colours of the drinks have no effect on the measurements.

\section{Conclusions}

The metallic electrode proposed in this work can be used as a capacitance detector for the measurement of water vapour and, as a consequence, of substances that can change the vapour pressure of the water. It does not present the problem of surface renewal and was easy to operate. It provides a stable baseline and can be made as a portable instrument. The proposed method was employed to indi-

Table 2. Relationship between logarithm of capacitance signal and concentrations of water vapour and of ethanol.

\begin{tabular}{lccc}
\hline Sampling time / s & Equation* & Correlation coefficient & Detection limit / Pa \\
\hline 20 & $\operatorname{LogH}=-3.9843+0.0024 \times \mathrm{C}_{\mathrm{w}}$ & 0.9865 & 1733 \\
30 & $\mathrm{LogH}=-4.1166+0.0026 \times \mathrm{C}_{\mathrm{w}}$ & 0.9913 & 1651 \\
40 & $\mathrm{LogH}=-4.0052+0.0026 \times \mathrm{C}_{\mathrm{w}}$ & 0.9932 & 1608 \\
50 & $\mathrm{LogH}=-4.3210+0.0029 \times \mathrm{C}_{\mathrm{w}}$ & 0.9931 & 1551 \\
20 & $\mathrm{LogH}=1.7978-0.0167 \times \mathrm{C}_{\mathrm{e}}$ & 0.9927 & 0.9924 \\
40 & $\operatorname{LogH}=1.4948-0.0139 \times \mathrm{C}_{\mathrm{e}}$ & 0.9969 & \\
60 & $\operatorname{LogH}=1.9495-0.0177 \times \mathrm{C}_{\mathrm{e}}$ & & \\
\hline
\end{tabular}

$* \mathrm{H}=$ the capacitance signal measured as peak height. $\mathrm{C}_{\mathrm{W}}=$ the concentration of water vapour in the range from 1705 to 2197 Pa. $\mathrm{C}_{\mathrm{e}}=$ the concentration of ethanol in water in the range from $20 \%$ to $80 \%(\mathrm{w} / \mathrm{w})$ ethanol. 
Table 3. Indirect measurements of ethanol present in drinks with the capacitance flow-through detector.

\begin{tabular}{|c|c|c|c|}
\hline Sample number & Colour & Ethanol in present work / \% (by wt) & Reference value*/\% (by wt) \\
\hline 1 & colourless & $30.2 \pm 1.8$ & 32 \\
\hline 2 & yellowish-brown & $33.5 \pm 1.7$ & 35 \\
\hline 3 & colourless & $34.9 \pm 1.5$ & 36 \\
\hline 4 & colourless & $41.0 \pm 1.3$ & 40 \\
\hline 5 & yellowish-brown & $31.6 \pm 1.9$ & 34 \\
\hline 6 & light brown & $36.2 \pm 1.4$ & 37 \\
\hline 7 & light yellow & $36.6 \pm 1.4$ & 37 \\
\hline 8 & colourless & $32.8 \pm 1.6$ & 35 \\
\hline 9 & colourless & $37.4 \pm 1.8$ & 36 \\
\hline 10 & yellowish-brown & $44.3 \pm 1.5$ & 42 \\
\hline 11 & colourless & $33.8 \pm 1.4$ & 34 \\
\hline 12 & colourless & $31.4 \pm 1.4$ & 31 \\
\hline 13 & colourless & $35.0 \pm 2.1$ & 35 \\
\hline 14 & yellowish-brown & $35.0 \pm 1.3$ & 35 \\
\hline 15 & violet & $38.4 \pm 1.4$ & 38 \\
\hline 16 & brown & $34.2 \pm 2.2$ & 35 \\
\hline 17 & light brown & $35.8 \pm 1.8$ & 36 \\
\hline 18 & light yellow & $38.6 \pm 1.6$ & 40 \\
\hline 19 & yellowish-brown & $34.0 \pm 1.6$ & 35 \\
\hline
\end{tabular}

*Reference values provided by the laboratory of drink analysis, at the Institute of Chemistry of São Carlos, University of São Paulo.

rectly determine ethanol in drinks. The capacitance detector can be used for "in line" measurement of ethanol content of drinks in beverage industries.

\section{Acknowledgements}

The authors are grateful to Conselho Nacional de Desenvolvimento Científico e Tecnológico (CNPq) and Fundação de Amparo à Pesquisa do Estado de São Paulo (FAPESP) for financial support. SJ Liu acknowledges FAPESP for a post-doctoral fellowship (Process No. 95/04227-0). Prof. Douglas Wagner Franco and Dr. Ronaldo Ferreira do Nascimento, Institute of Chemistry of São Carlos, University of São Paulo, are thanked for reference analysis of the drink samples. Prof. Carol H. Collins is thanked for the English improvement.

\section{References}

1. Bos, M.; van Willigen, J.H.H.G.; van der Linden, W.E. Anal. Chim. Acta 1984, 156, 71.

2. Bos, M. Anal. Chim. Acta 1982, 135, 249.

3. Rosen, M.J.; Hua, X.; Bratin, P.; Cohen, A.W. Anal. Chem. 1981, 53, 232.
4. Emons, H.; Schmidt, T.; Stulík, K. Analyst 1989, 114, 1593.

5. Gebbert, A.; Alvarez-Icaza, M.; Stcklein, W.; Schmid, R.D. Anal. Chem. 1992, 64, 997.

6. Berggren, C.; Johansson, G. Anal. Chem. 1997, 69, 3651.

7. Winquist, F.; Spetz, A.; Lundstrm, I.; Danielsson, B. Anal. Chim. Acta 1984, 164, 127.

8. Bockris, J.O.'M.; Reddy, A.K.N.; Modern electrochemistry, v. 2, A Plenum/Rosetta Edition, 1973, p 630-632.

9. Janata, J. Principles of Chemical Sensors, Plenum Press, New York, 1989, p 231.

10. Lee, G.A. Anal. Proc. 1984, 21, 205.

11. Weast, R.C., Ed.; CRC Handbook of Chemistry and Physics, 67th Ed., CRC Press, Boca Raton, Florida, 1986, p D-190 and E-54.

12. Tubino, M. J. Flow Injection Anal. 1994, 11, 94.

13. Tubino, M.; Barros, F.G. Quím. Nova 1991, 14, 49.

14. Sawyer, D.T.; Roberts, J.L. Jr. Experimental Electrochemistry for Chemists, Wiley, 1974, p 204-207.

Received: May 6, 1998 